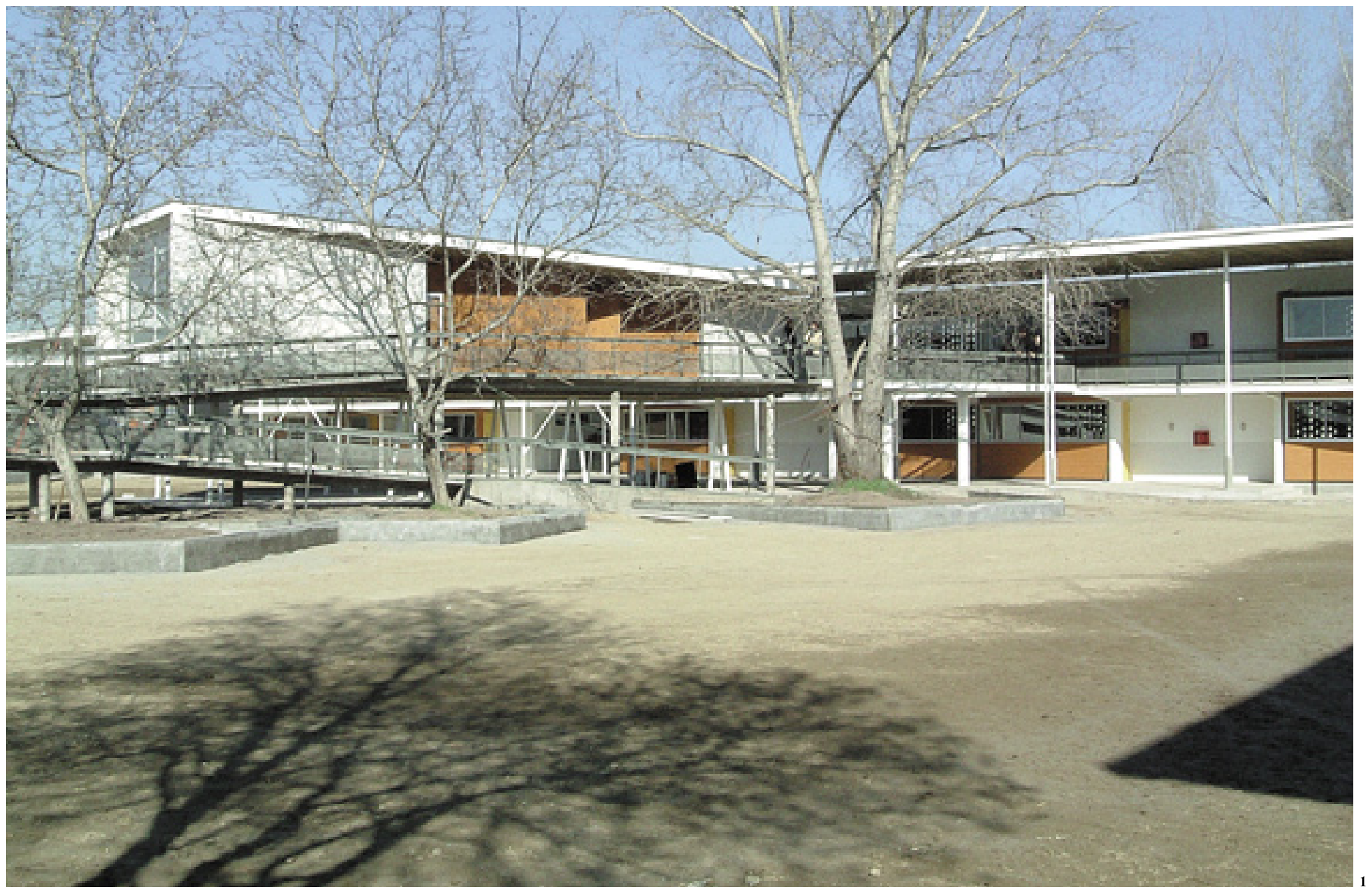

García, Aguiló, Arteaga, Pedraza La Pintana, Chile

En la periferia santiaguina el colegio sigue siendo una pieza excepcional, singular y distinguible del tejido homogéneo y denso de casas y patios. Esta escuela se instala con propiedad en La Pintana pero no aparece como un monumento en el barrio: más bien actúa como un elemento integrador entre dos áreas del vecindario, a través de un corredor y una serie de pabellones pensados para el uso abierto de toda la comunidad. Palabras clave: Arquitectura - Chile, establecimientos educacionales, colegios, escuelas públicas, Reforma Educaciona.

On the outskirts of Santiago the school buildings still stand out in the dense homogeneous tissue of houses and yards. This school is installed in La Pintana, but it does not stick out like a monument in the neighborhood. Instead it acts as an integrating element between two sectors, through a corridor and a series of buildings planned for open use by the whole community.

Key words: Architect

\title{
Escuela Juan de Dios Aldea
}

El encargo de esta escuela nace del convenio de asistencia del Programa de Políticas Públicas que tiene la Universidad Católica de Chile con los municipios.

La municipalidad de La Pintana encarga el proyecto para la escuela básica Juan de Dios Aldea, la cual debía ser trasladada por la demolición del establecimiento existente (originada por la construcción del nuevo acceso sur a Santiago).

$\mathrm{El}$ terreno adquirido por el municipio se ubica en lo que originalmente correspondía a un loteo de parcelas agrícolas; por ello existen servidumbre de canales de riego y algunos árboles de tamaño importante dentro del predio. Este paisaje agrícola fue una cuestión importante a preservar.

Otra condición importante del emplazamiento es que el terreno tiene dos frentes: uno hacia la población "El Castillo", comunidad hacia la cual está orientada la escuela, y otro hacia la calle Miguel Ángel, el cual conecta con las vías principales de la comuna.

El proyecto, entonces, aborda dos cuestiones. Por un lado el edificio como una apertura hacia una escala mayor de paisaje abierto, de la cordillera; y por otro como una conexión de la población al sistema mayor de la comuna.

Por ello se tomó la decisión de agrupar las aulas de clases en un edificio barra -que se hace cargo de la dimensión total del predio- y los programas de uso común se disponen construyendo la escala intermedia y constituyendo ámbitos distintos dentro de un total continuo.

El edificio barra se plantea como una galería que se asoma a la cordillera y se abre al oriente, en que las aulas agrupadas en dos niveles constituyen la vida cotidiana de la escuela en sus recorridos. Las cabezas de esta barra son la administración de la escuela, ubicada en el acceso para la población El Castillo, y las áreas de uso comunitario (como el auditorio y el equipamiento deportivo) en el otro extremo, abiertas a la comunidad con acceso por calle Miguel Ángel. Para el lado poniente del edificio de aulas se planteó una pantalla de albañilería, que por un lado tamiza la luz del 

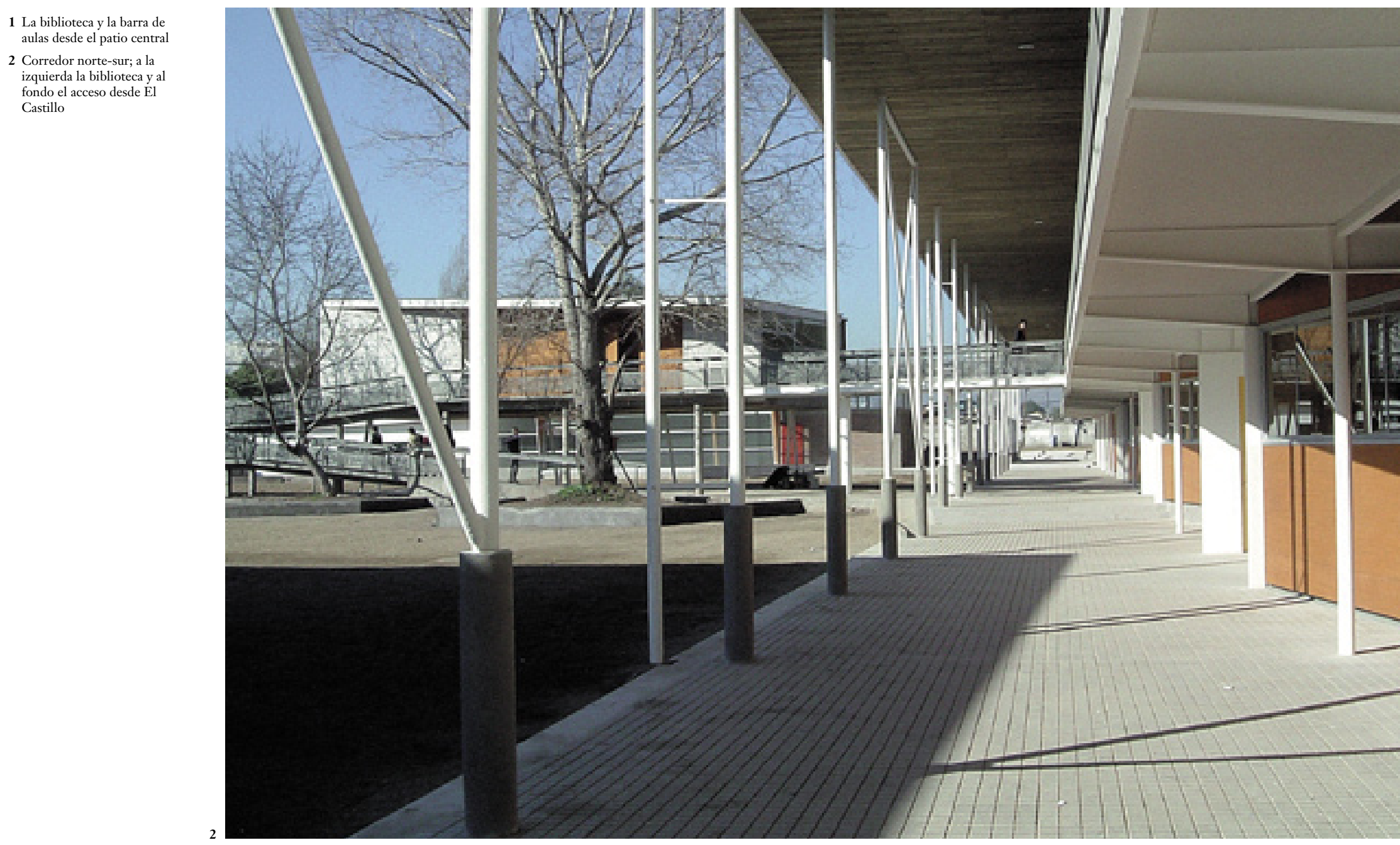

poniente y a su vez construye un cierro seguro hacia el patio de estacionamientos.

El patio central está planteado como un interior que se abre hacia la cordillera y los huertos vecinos, mediado por los edificios de uso común, como el casino, la multicancha techada y la biblioteca sobre pilotes, únicos elementos urbanizadores de un exterior que busca mantener la condición inicial de amplitud del predio. La preexistencia de tres nogales y el requerimiento de una rampa para minusválidos se aprovechan como una instancia de articulación lúdica entre el patio y el segundo nivel de la escuela.

El edificio debía ser además una construcción económica, por lo que se utilizan materiales sencillos, estructura metálica y hormigón armado, en que los cerramientos de albañilería y las terminaciones son vistas, privilegiando la aplicación de madera en los cielos de los espacios comunes y los frentes de aulas de clases. En el patio se prioriza la aplicación de pavimentos en los lugares de sombras y en la galería. ARQ

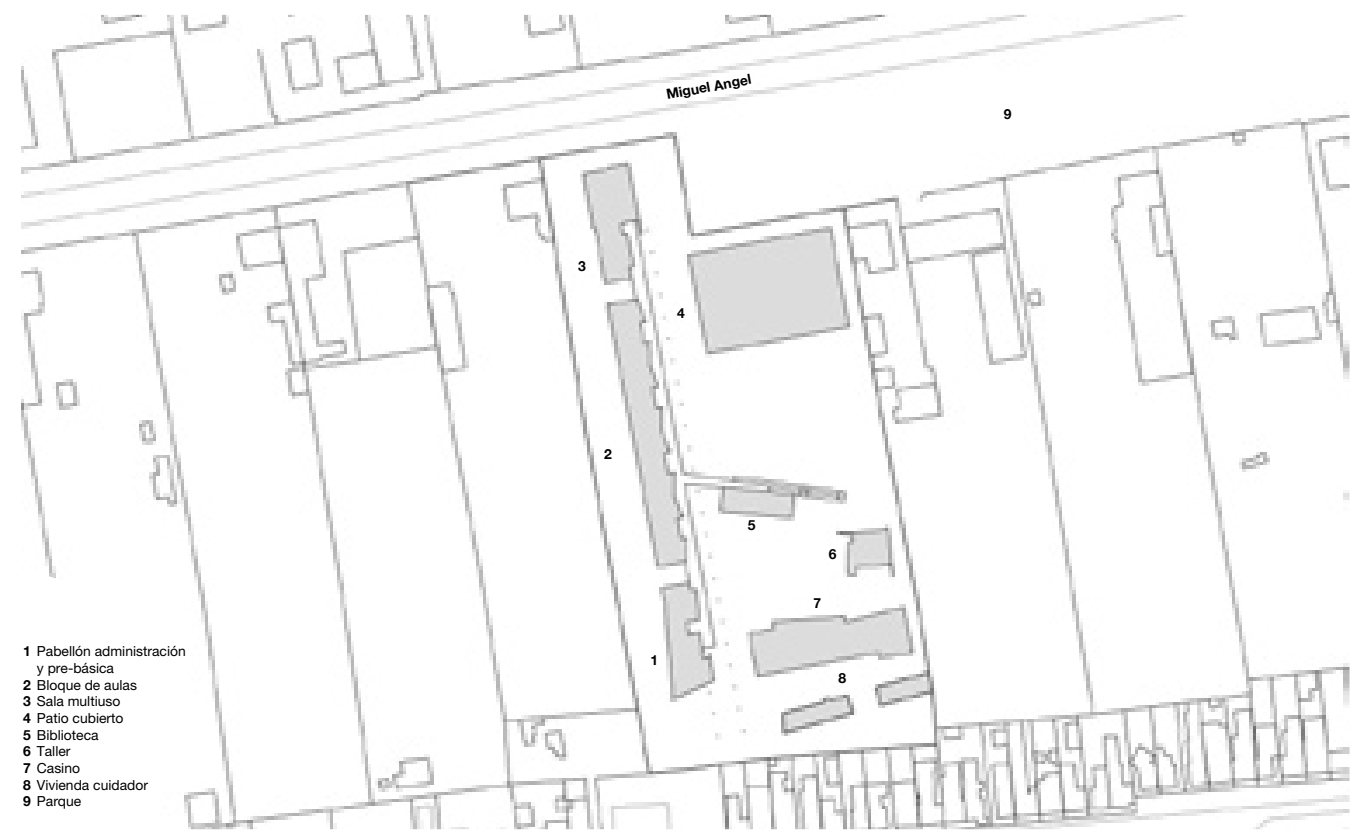

Planta emplazamiento 


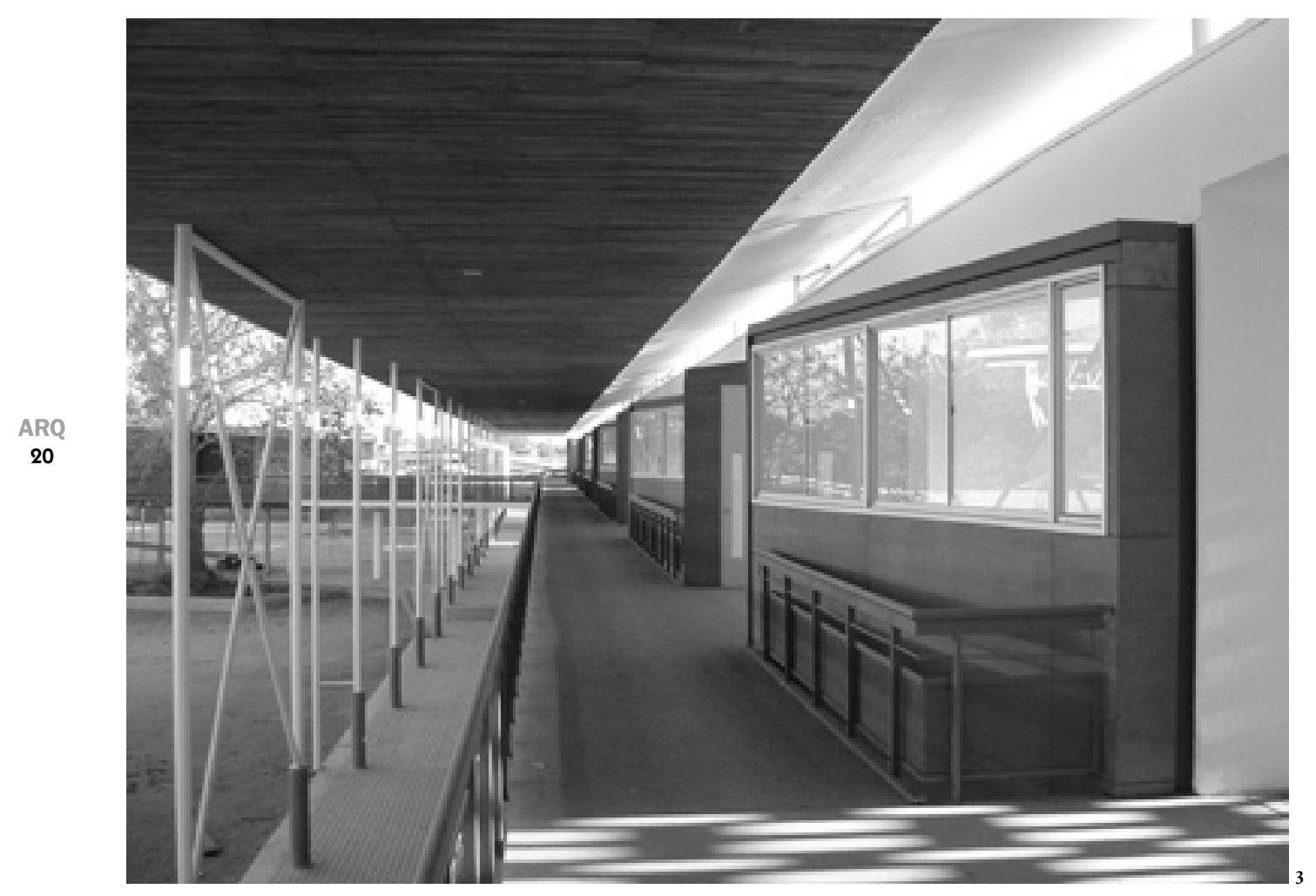

3 Corredor norte-sur, segundo

nivel barra de aulas

4 Acceso a patio cubierto desde

corredor norte-su

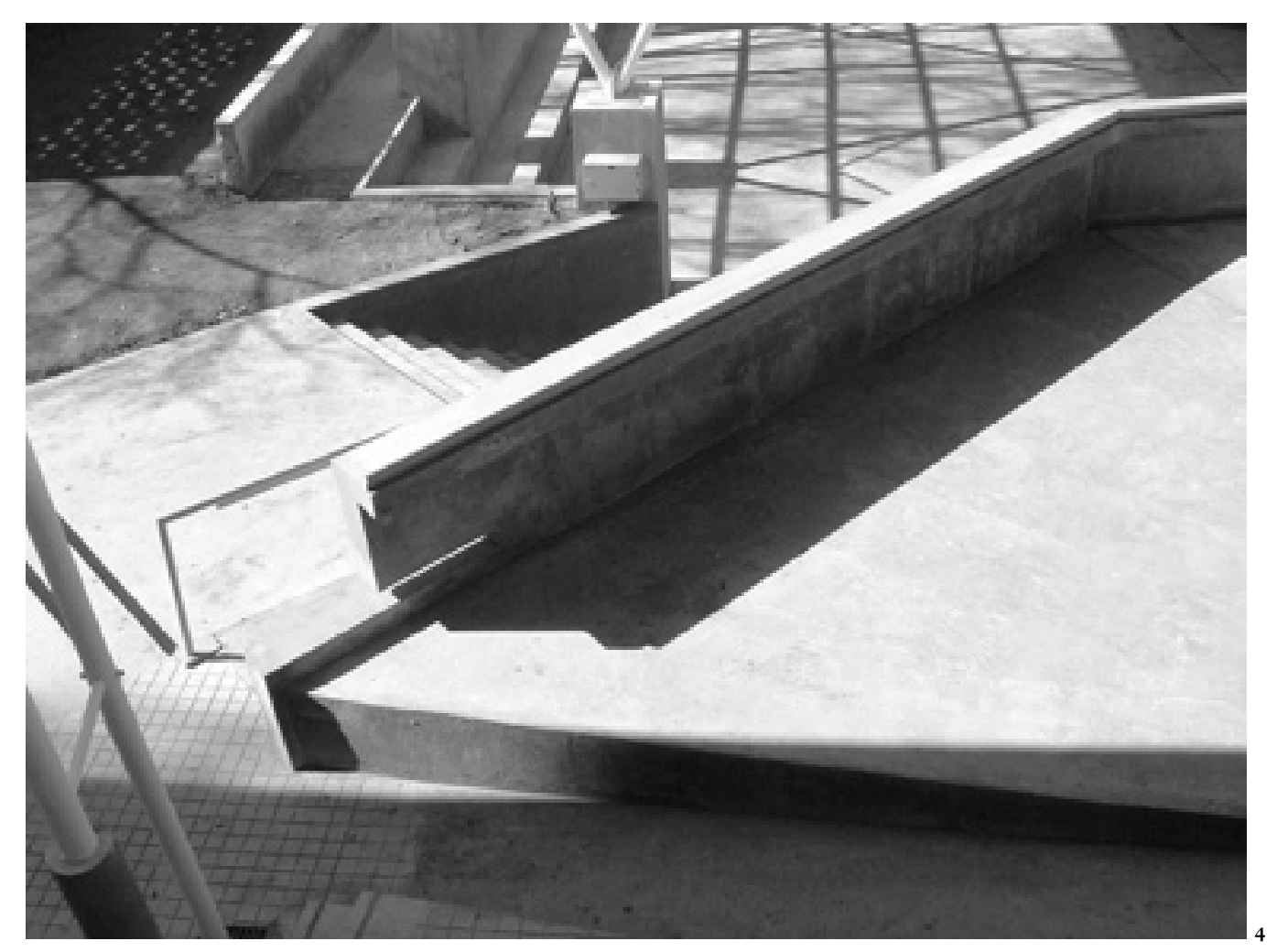

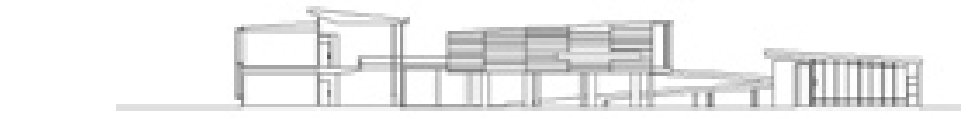

Corte A A'

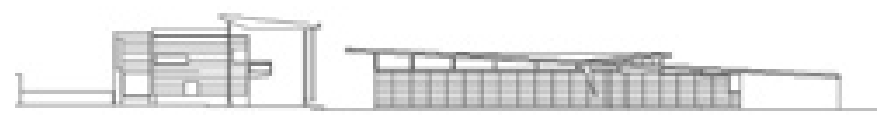

Corte BB

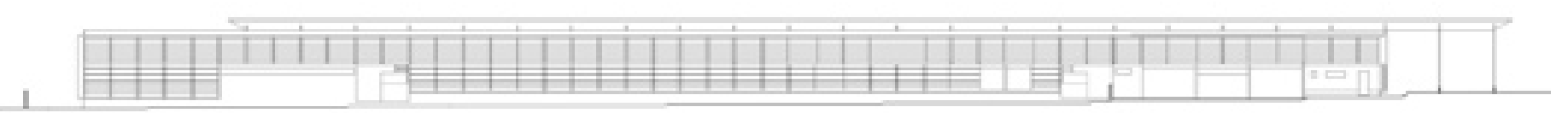



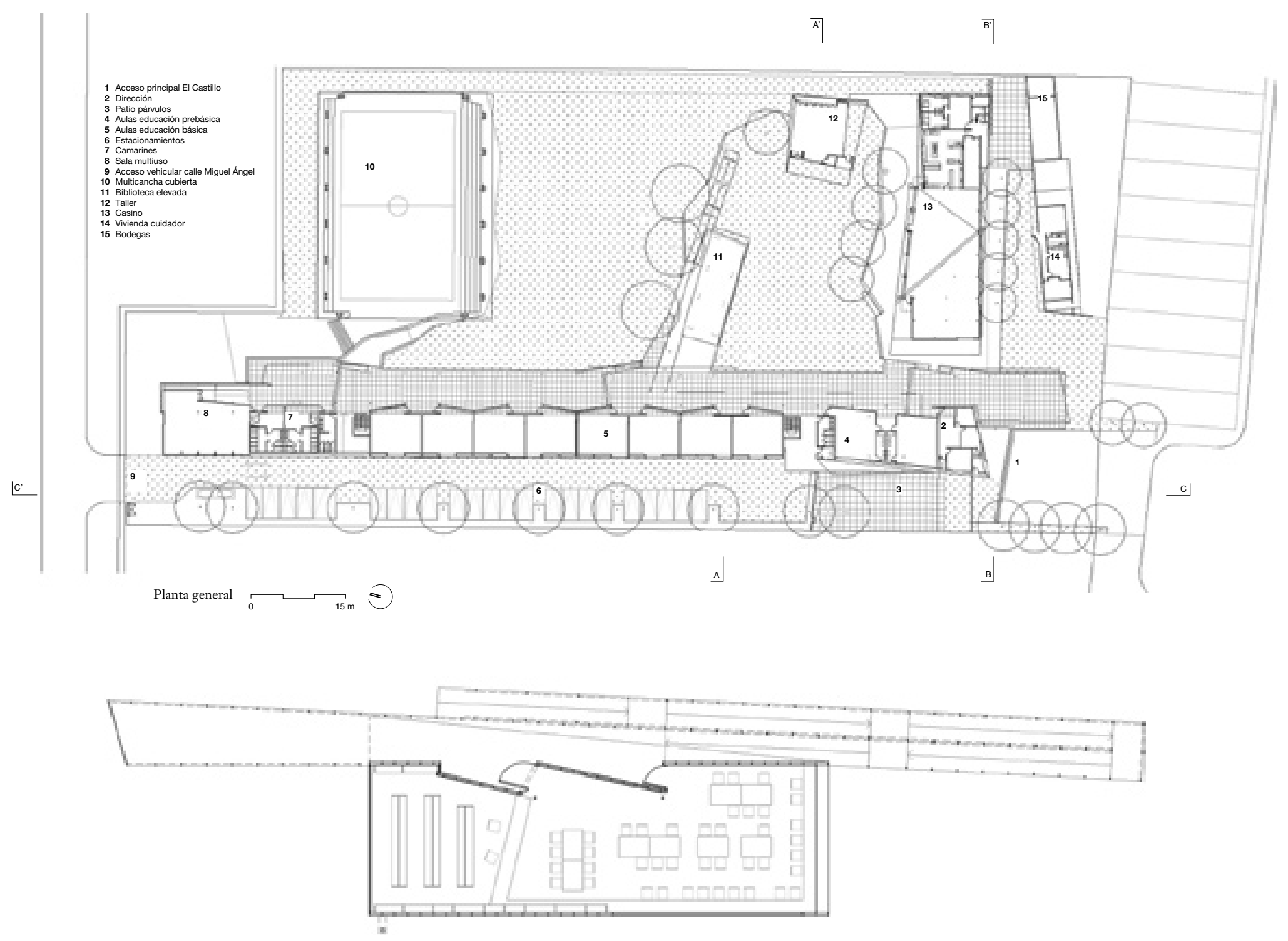

Planta pabellón elevado biblioteca

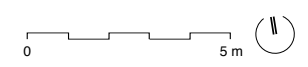

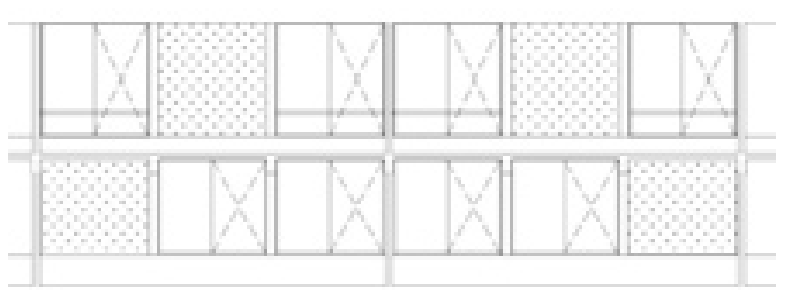

Elevación tipo aula educación básica

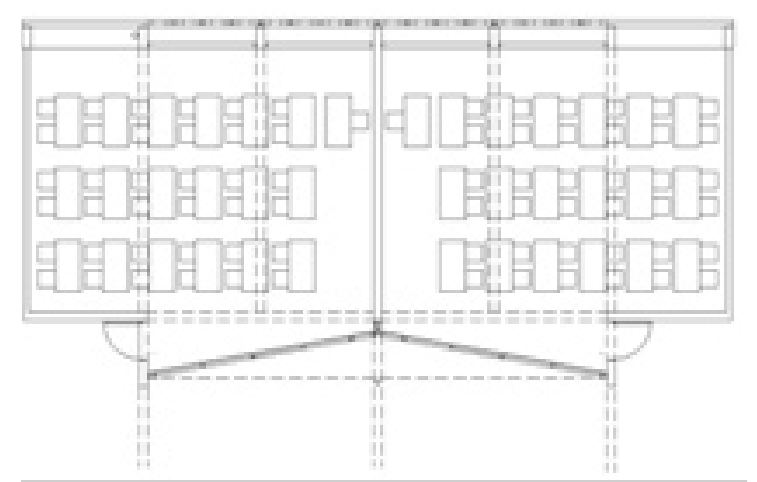

Planta tipo aula educación básica

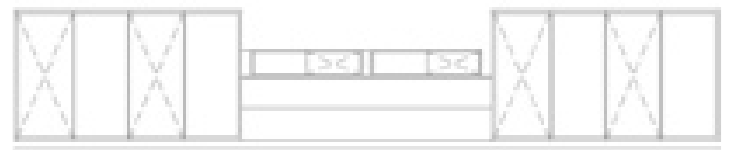

Elevación tipo aula educación pre-básica

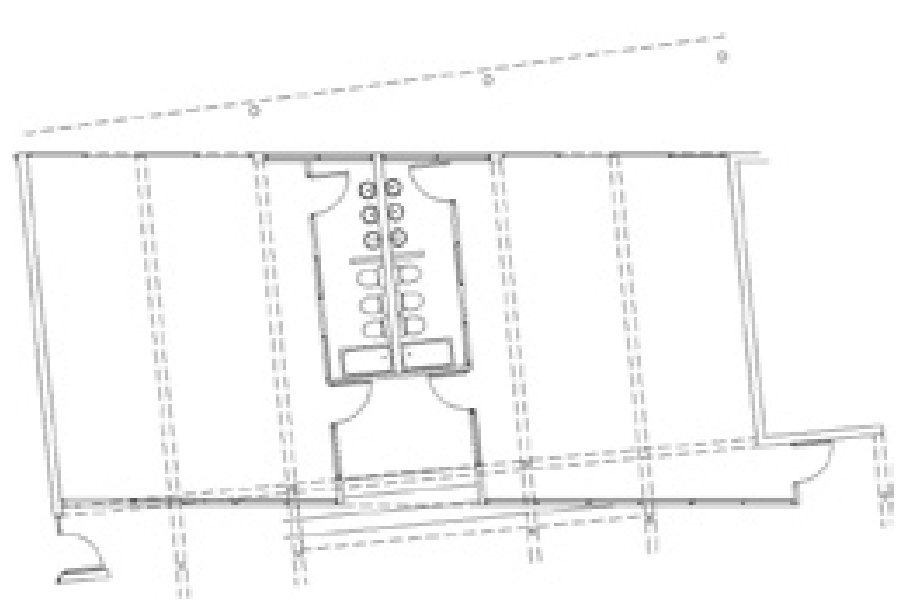

Planta tipo aula educación pre-básica 

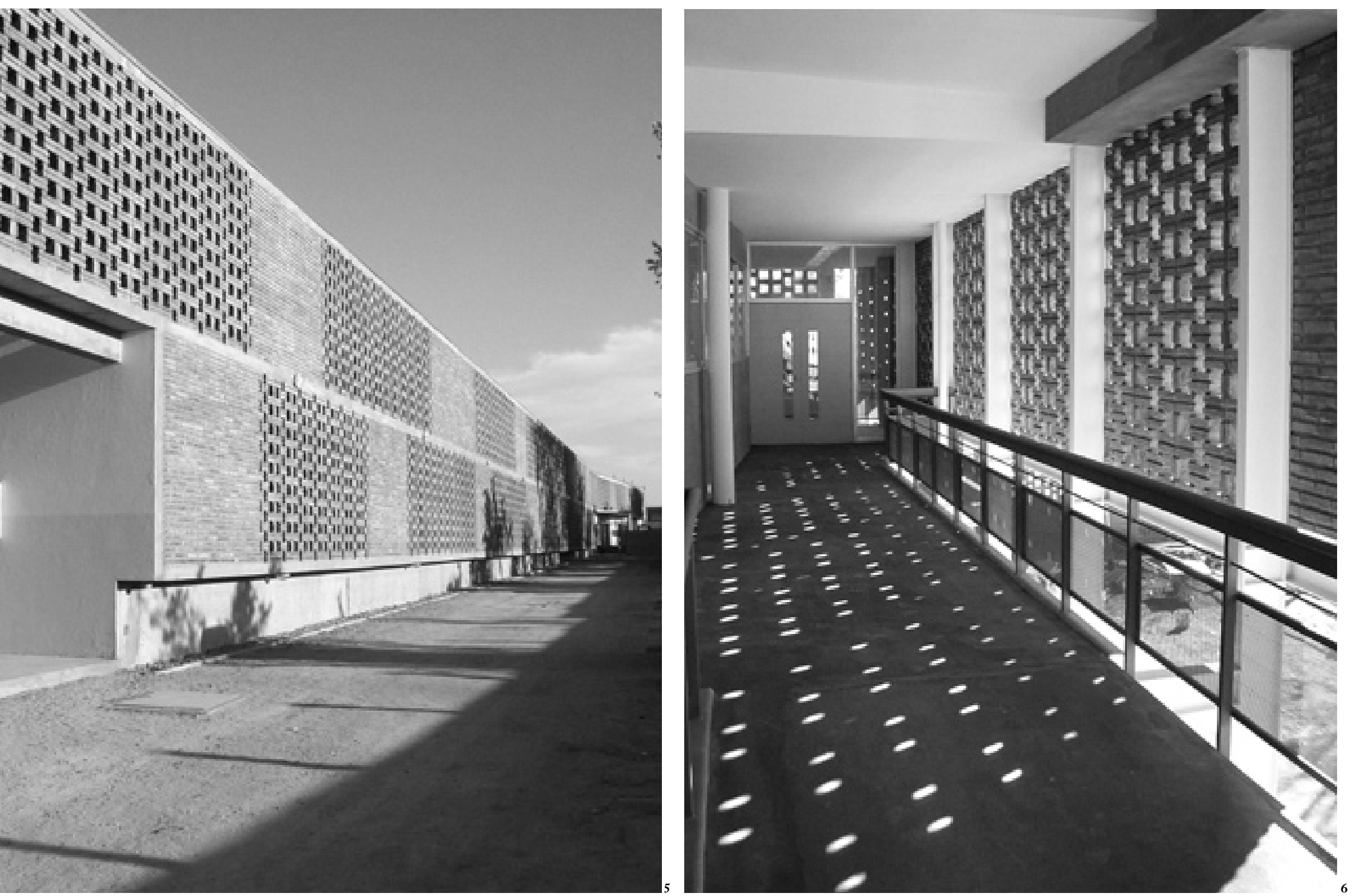


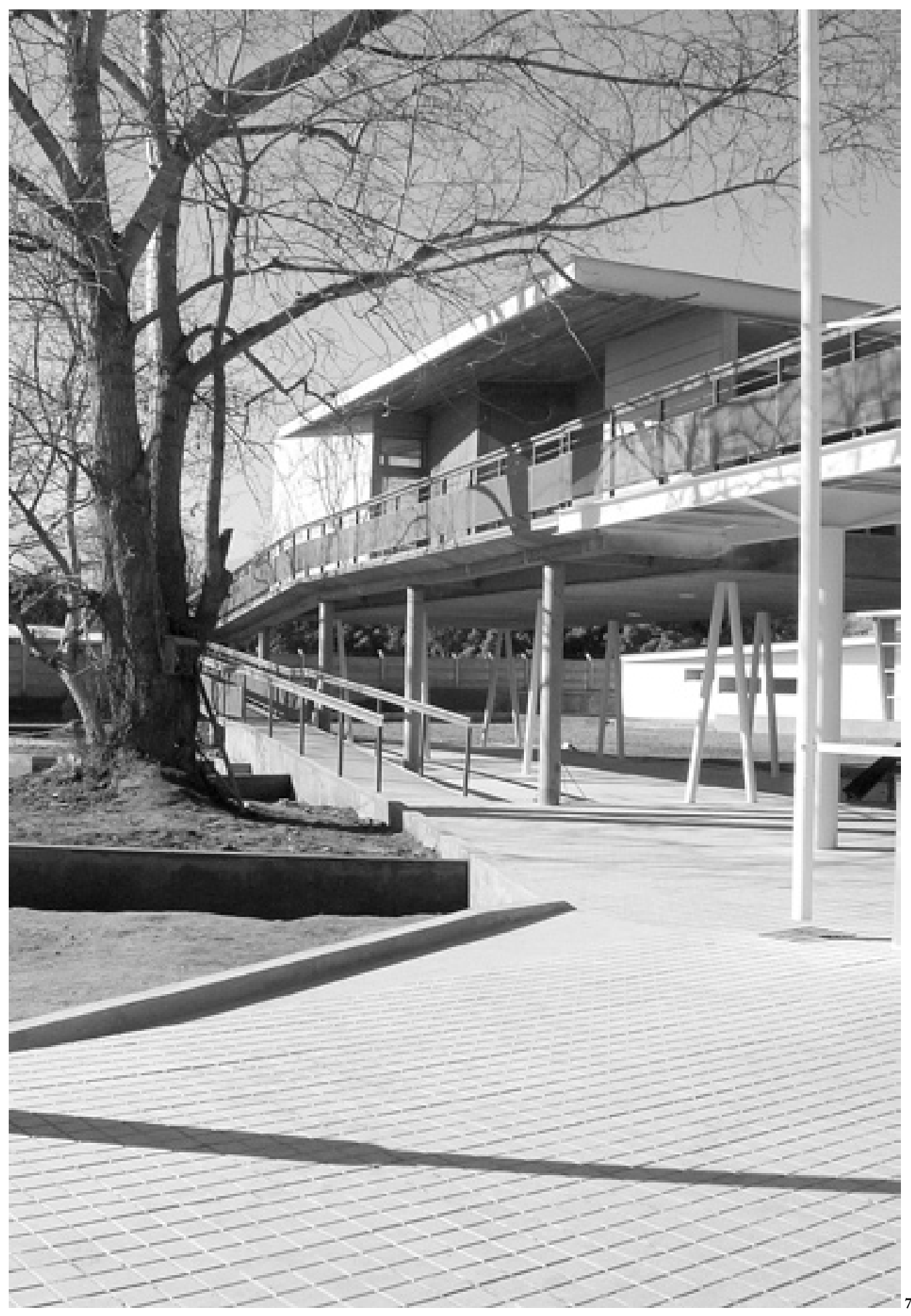

